\title{
LAND REHABILITATION WITH THE USE OF BIOLOGICAL GEOTEXTILES, IN TWO DIFFERENT COUNTRIES
}

\section{Reabilitação de Solos com Uso de Geotêxteis Biodegradáveis em dois Países}

Antonio José Teixeira Guerra

Department of Geography,

Federal University of Rio de Janeiro

Rio de Janeiro/RJ - Brazil

antoniotguerra@gmail.com

José Fernando Rodrigues Bezerra

Department of Geography,

Federal University of Rio de Janeiro,

School of Applied Sciences,

The University of Wolverhampton

Rio de Janeiro/RJ - Brazil /

Wolverhampton WV1 1SB - United Kingdom

fernangeo@yahoo.com.br

\section{Luis Dias da Mota Lima}

Department of Geography,

Federal University of Rio de Janeiro

Rio de Janeiro/RJ - Brazil

luizdmlagro@yahoo.com.br

Jane Karina Silva Mendonça

Secretaria de Estado do Planejamento e Orçamento, Instituto Maranhense de Estudos Socioeconômicos

e Cartográficos (IMESC)

São Luis/ MA - Brasil

janeksm@yahoo.com.br

Tatiana Teixeira Guerra

Department of Geography,

Federal University of Rio de Janeiro

Rio de Janeiro/RJ - Brazil

tatianatguerra@gmail.com

\section{Christl Buhmann}

Agricultural Research Council-Institute for Soil,

Climate and Water

Private Bag X79

Pretoria 0001 - South Africa

cbuhmann@arc.agric.za
David Garry Paterson

Agricultural Research Council-Institute for Soil,

Climate and Water

Private Bag X79

Pretoria 0001 - South Africa

garry@arc.agric.za

Gerry Pienaar

Agricultural Research Council-Institute for Soil,

Climate and Water

Private Bag X79

Pretoria 0001 - South Africa

gerry.pienaar@deaet.ecape.gov.za

J. Piet Nell

Agricultural Research Council-Institute for Soil,

Climate and Water

Private Bag X79

Pretoria 0001 - South Africa

garry@arc.agric.za

Nthanyiseni Elvis Mulibana

Agricultural Research Council-Institute for Soil,

Climate and Water

Private Bag X79

Pretoria 0001 - South Africa

garry@arc.agric.za

Pieter Willem Van Deventer

North West University,

School for Environmental Science and Development

Potchefstroom 2520 - South Africa

garry@arc.agric.za

Michael Augustine Fullen

School of Applied Sciences,

The University of Wolverhampton

Wolverhampton WV1 1SB - United Kingdom

m.fullen@wlv.ac.uk 
ABSTRACT: This paper assesses the role of biological geotextiles on non-agricultural erosion environments, based on studies in the mine tailings Gauteng Province (South Africa) and urban area of São Luis City (Brazil). Gauteng Province (South Africa) has suffered immense problems related to sustainable rehabilitation of mine dumps. This is a huge challenge, as wastes are highly susceptible to both water and wind erosion. Establishing a grass cover to reduce erosion is the dominant reclamation method. Covering the slopes with biological geotextiles might constitute another option for mining companies to reduce erosion and aid natural re-vegetation. The objective of the waste part of this study was to determine the beneficial effect of palm mat cover on erosion control, using rainfall simulation. Results clearly illustrated that application of palm-mats more than halved the sediment load in runoff, thereby having the potential to effectively stabilize tailing dam slopes. Covering tailings with palm-mats did not reduce runoff or improve water infiltration, however. In São Luis City, biological geotextile mats were constructed from palm leaves which are an effective, sustainable and economically-viable soil conservation technique. At Sacavém Community biological geotextile mats were used in association with barriers of wooden stakes and the construction of terraces along contour lines. The aim is to minimize soil erosion, by intercepting rainfall, retarding runoff velocity and sediment loss.

keywords: Biological geotextile. Sustainable development. Rehabilitation. Mine tailings. Buriti mats.

RESUMO: O objetivo desse artigo é avaliar o papel dos geotêxteis biodegradáveis em áreas não-agrícolas, levando em consideração os estudos desenvolvidos na Província de Gauteng (África do Sul) e na área urbana do municipio de São Luis (Brasil). Nas ultimas décadas, a Provincia de Gauteng vem sofrendo imensos problemas relacionados à reabilitação sustentável de áreas com rejeito de mineração. Este é um grande desafio, pois esses rejeitos são altamente suscetiveis à erosão, tanto pela água, como pelo vento. A proteção dessas superficies por uma cobertura de gramíneas para reduzir a erosão é um método sugerido por parte dos pesquisadores. A utilização de geotêxteis biodegradáveis constitui outra solução para as companhias de mineração, para a diminuição da erosão superficial e auxílio para o processo de re-vegetação natural. Esse estudo teve como objetivo determinar os efeitos positivos da utilização de geotêxteis construídas com fibras de palmeiras no controle da erosão superficial, a partir do uso de um simulador de chuvas. Os resultados demonstraram claramente que a aplicação destas geotêxteis reduziu pela metade a carga de sedimentos no escoamento superficial, tendo também o potencial para estabilizar as encostas de rejeitos de mineração. A aplicação dos geotêxteis nos rejeitos não diminui o escoamento superficial, nem melhorou a infiltração da água no solo. Na cidade de São Luís, os geotêxteis biodegradáveis foram construidos a partir de folhas de palmáceas, que são eficientes, sustentáveis e economicamente viáveis, como uma técnica de conservação do solo. Na comunidade de Sacavém os geotêxteis foram usados em associação com paliçadas de madeira e foram feitos terraços, ao longo das curvas de nivvel. O objetivo foi o de minimizar a erosão do solo, a partir da interceptação da chuva, que retardou a velocidade do escoamento superficial e, consequentemente diminuiu a perda de sedimentos.

Palavras-chave: Geotêxteis biodegradáveis. Desenvolvimento sustentável. Reabilitação. Rejeitos de mineração. Geotêxtil de Buriti. 


\section{INTRODUCTION}

Soil degradation by erosion is one of the world's most serious environmental problems, causing extensive loss of cultivated and potentially productive soil and decreased crop yields (FULLEN; CATT, 2004; MORGAN, 2006). It has been estimated that some 4000 million tonnes of soil per year have been eroded from the continental USA since the 1930s (FULLEN; CATT, 2004). Major causes of water and wind erosion include deforestation, overgrazing and mismanagement of arable land. By removing vegetation cover the erosion-resisting capacity of the soil becomes disturbed. Most rehabilitation efforts on degraded lands involve different techniques which could be represented by traditional engineering or soil bioengineering.

Soil bioengineering has been recognized as a technique to provide slope stabilization and erosion control, taking into account both traditional engineering and biological principles, using living and dead vegetation, associated with construction materials. Normally, bioengineering projects are less costly than conventional engineering and they have been applied in different sites, such as stream bank stabilization, roadside slopes, river restoration, hillslopes, mine tailings and gully slopes. These different environments have distinct characteristics, but common locations include agricultural and non-agricultural (e. g. mine tailings and urban areas) sites.

For this paper we have considered two different situations, in terms of non-agricultural erosion, in order to contribute towards the assessment and rehabilitation of degraded areas. They include: mine tailing erosion in South Africa and urban gully monitoring and land rehabilitation in São Luís City, Brazil.

Mine wastes have been generated for a long period of human history, and mining activity has accelerated significantly during the $20^{\text {th }}$ century. The mine wastes areas, such as tailing dams and dumps, represent a potential source of contamination to the environment, mainly when heavy metals and acid are released in large amounts (LEDIN; PEDERSEN, 1996).

Mining has been the backbone of the South African economy since the discovery of diamonds and gold in the late $19^{\text {th }}$ century. Intensive mining activities, however, not only fuel economic growth, can also have devastating environmental impacts. Large volumes of mine waste, such as tailings, have been generated in some areas and sustainable rehabilitation of mine dumps is a huge challenge.

Land degradation is attributed to both environmental and socio-economic conditions, including unauthorized and/or inefficient urban development and planning (SOBREIRA, 1989; GOUDIE, 1994; GUERRA, 2000; FULLEN, 2003). Soil erosion in urban areas is generally associated with irregular population settlement. Consequently, inappropriate land management, including poor maintenance of vegetal cover, is the principal cause of water erosion (CASAL et al., 1999; VALENTIN et al., 2008; MUNRO et al., 2008). Vegetation cover is often undervalued in terms of its control over landscape incision (HOWARD, 1997; POESEN et al., 2003).

São Luís, like many other Brazilian cities, has experienced rapid population growth in recent decades, which has created a series of socio-economic and environmental problems, including accelerated soil erosion. Sacavém is one of these communities where natural and human factors contribute to severe gully erosion (SATHLER et al., 2005; GUERRA et al., 2005; BEZERRA et al., 2010). Rapid population and urban growth has intensified problems, compounded by poor planning and improper soil use.

Biological geotextiles are potentially excellent biodegradable and environmentally-friendly materials useful for soil conservation. The application of biological geotextiles, constructed from the palm leaves of Hyphaene coriacea. (Lala palm) and Mauritia flexuosa (Buriti), has been investigated at the Laboratory of Environmental Geomorphology and Land Degradation (Brazil) and The Agricultural Research CouncilInstitute for Soil, Climate and Water (South Africa). The integrated research programme BORASSUS is supported by the European Union under contract number INCO-CT-2005-510745 and was carried out from 2005-2009 with the participation of research groups from Europe (Belgium, Hungary, Lithuania and the United Kingdom), Africa (The Gambia and South Africa), South-East Asia (China, Thailand and Vietnam) and South America (Brazil). The overall 
objective of the BORASSUS Project was to evaluate the long-term effectiveness of this technology in controlling soil erosion and their sustainability and economic viability in these countries.

The main objective of this paper is to analyse the role of biological geotextiles on non-agricultural environments, considering different methods and techniques applied on a mine tailing (South Africa) and an urban area (Sao Luis City, Maranhão State). It considers the principles of soil bioengineering related to the use of geotextiles using different methods.

\section{STUDY AREAS}

Gauteng Province (South Africa) and São Luís City (Brazil), were selected as case study locations for this research (Figure 1), as they were experiencing different land degradation problems, with the potential of remedial use of bioengineering techniques.

\section{Gauteng (South Africa)}

Gauteng is the smallest of South Africa's nine provinces, covering $\sim 16,600 \mathrm{~km}^{2}$ or $1.4 \%$ of the country. It has the second-largest population $(9,525,571$ in 2006), by far the highest population density and the highest per capita income level, contributing $33 \%$ to the national economy and a remarkable $10 \%$ to the GDP of the entire African continent. Gauteng is the most urbanized province with $97 \%$ of its population living in urban centres. Its capital, Johannesburg, is the largest city in South Africa and one of the world's youngest major cities, having been founded in 1886, and gold was discovered in the area (DEPARTMENT OF AGRICULTURE, CONSERVATION AND ENVIRONMENT, 2004).

Gauteng is a summer-rainfall area, characterized by hot summers and cold winters with frost. The mean annual precipitation varies from

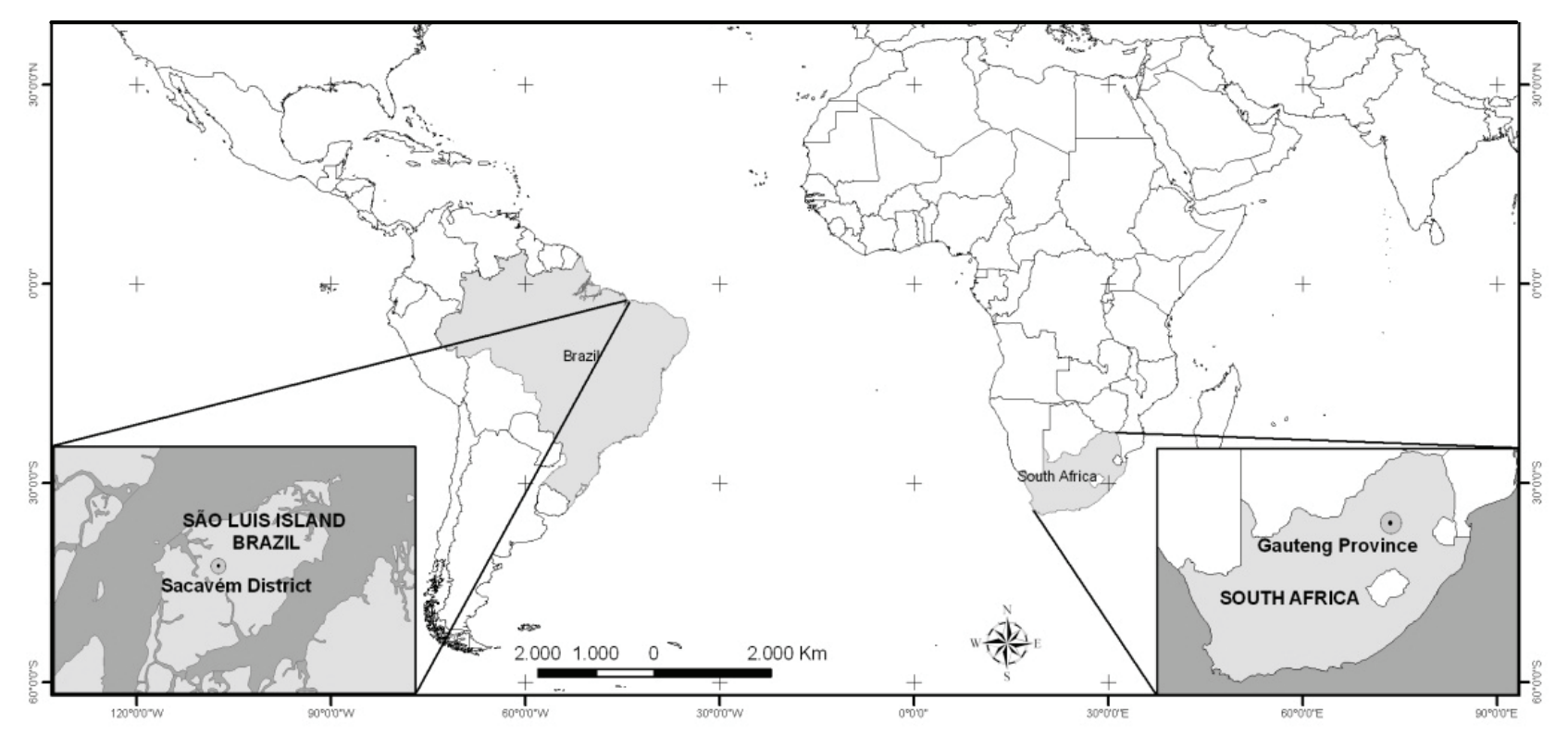

Figure 1: Sites used in this study.

574 to $900 \mathrm{~mm}$, with an average of $672 \mathrm{~mm}$. The mean annual temperature across the Province varies from $\sim 15$ to $19^{\circ} \mathrm{C}$, with an average of $16.2^{\circ} \mathrm{C}$, average minimum and maximum temperatures are 9.8 and $24.5^{\circ} \mathrm{C}$, respectively (DEPARTMENT OF AGRICULTURE, CONSERVATION AND ENVIRONMENT, 2004).
Gauteng means "Place of Gold" in Sesotho and gold has been mined continuously since its discovery. These intensive mining activities, however, not only fuelled economic growth, but also had devastating environmental impacts. Large volumes of mine waste have been generated and tailing dams and dumps run as a continuous corridor from 
Krugersdorp in the west part of Johannesburg and Soweto to Boksburg in the east and on to Springs (Figure 2). This waste belt is situated in a densely populated urban area.

\section{São Luís City (Brazil)}

The settlement of São Luís was established in 1612 and has evolved in distinct phases. Rapid urban

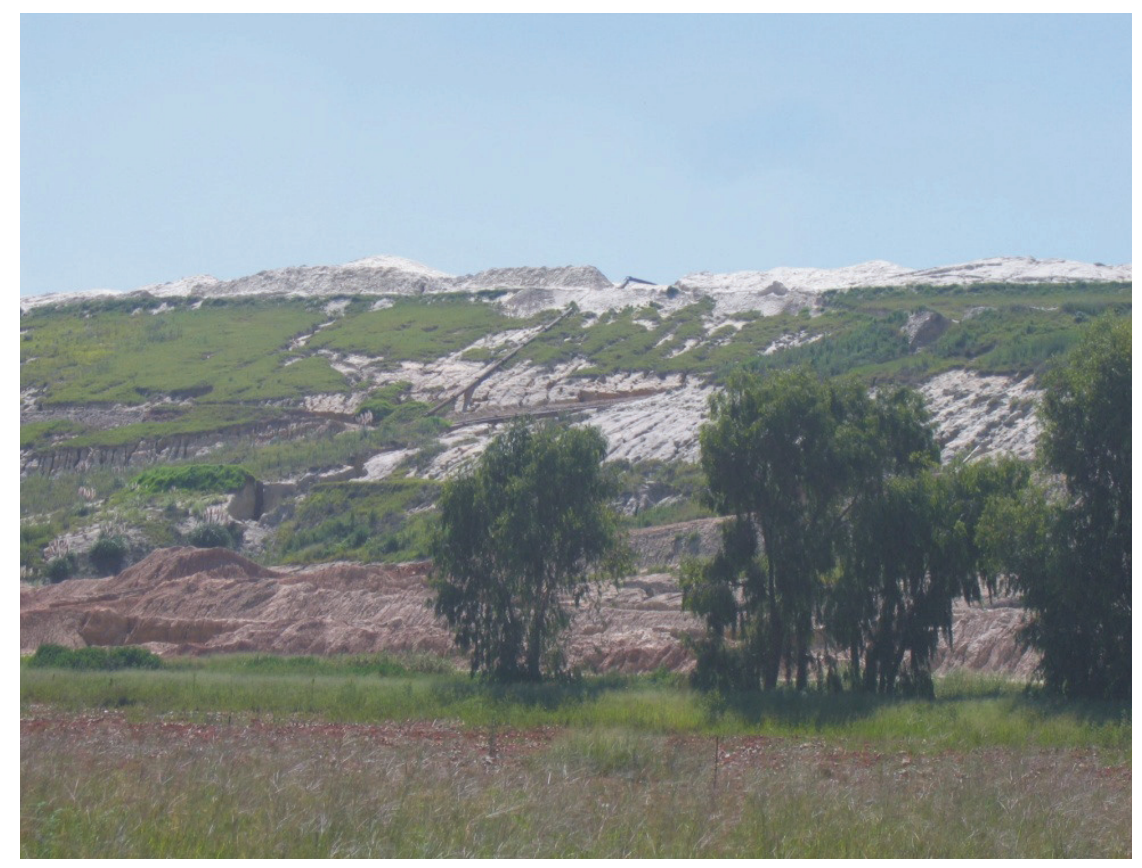

Figure 2: 'Mega-dump' of reprocessed gold tailings, south-east of Springs,

Gauteng Province. Heavy rains in February 2008 led to landslides that denuded large parts of the previously vegetated slope.

growth was associated with industrialization in the second half of the 18th century. The local lithology is mainly Tertiary sandstones and, to a lesser extent, shales, argillites and siltstones, all of which belong to the Barreiras Formation (GUERRA et al., 2004, 2005). Weathering on these rocks produces erodible soils, including lithosols, latosols, concretionary red/ yellow clay soils and concretionary plinthosols (MARANHÃO, 1998). Thus, erodible soils and regolith are subject to high erosion rates, especially on steeper slopes subject to additional human interventions. Furthermore, although regional slopes are quite gentle, there is localized high relative relief. Secondary mixed forest and brushwood are the dominant vegetal cover adjacent to the urban gullies. The local climate is humid tropical, with average annual temperatures of $26^{\circ} \mathrm{C}$, reaching higher values in October-December and lower from April-June (FONSECA, 1995). Rainfall distribution is irregular, marked by two very distinct seasons (rainy and dry). The highly seasonal erosive rains incise a complex series of soil erosion landforms, mainly gullies.

\section{MATERIALS AND METHODS}

Materials and methods for this paper are divided into two topics, which relate to the study areas, where the effects of biological geotextiles on the stability of non- agricultural environments have been tested.

\section{Gauteng Province (South Africa)}

Rainfall simulation was selected as an investigative tool, as it provides a very reliable approach to obtaining interrill erodibility data for a range of representative conditions, such as slope angle, rainfall intensity and water composition (GABRIELS et al., 2002). Laboratory experiments also enable a broad range of samples to be investigated. A particular 
field site does not offer the range of waste and slope conditions that can be found elsewhere in the region or country. Experiments were conducted on 10 mine waste samples, first on the bare tailings and then on the same materials covered with biological geotextiles, manufactured from leaves of the Hyphaene coriacea (Lala palm). Material selection was based on the most common commodities mined in South Africa, namely gold, platinum, diamonds, coal, chromium, silica and vanadium (Table 1). rain. The volumes percolating through the tailings were recorded at 2 min intervals during an event of 2 hours for each storm. Timed run-off samples were also collected at $2 \mathrm{~min}$ intervals, weighed, oven-dried at $105^{\circ} \mathrm{C}$ and re-weighed to determine runoff rate and sediment yield. Measurements were conducted in duplicate.

After the first run (Run 1) the samples were allowed to dry at room temperature for one week and were then subjected to the same treatment for a

Table 1: Locations and selected properties of mine wastes.

\begin{tabular}{|c|c|c|c|c|c|c|c|c|c|c|c|c|c|}
\hline \multirow{2}{*}{ Location } & \multirow{2}{*}{$\begin{array}{l}\text { Metal/ } \\
\text { mineral } \\
\text { mined }\end{array}$} & \multirow{2}{*}{ 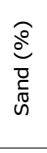 } & \multirow{2}{*}{ 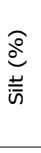 } & \multirow{2}{*}{ 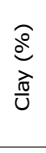 } & \multirow{2}{*}{$\frac{*}{\frac{\pi}{a}}$} & \multirow{2}{*}{ 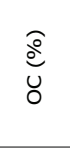 } & \multirow{2}{*}{ 氙 } & \multirow{2}{*}{ 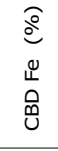 } & \multicolumn{5}{|c|}{ Dominant clay minerals (\%) } \\
\hline & & & & & & & & & Ka & $\mathrm{Mi}$ & $\begin{array}{l}\text { Tc } \\
\text { Py }\end{array}$ & Sm & Qz \\
\hline Springs & Gold & 67 & 29 & 2 & 3.9 & 0.09 & 2.4 & 0.16 & 5 & 23 & 0 & 0 & 59 \\
\hline Northam & Platinum & 65 & 20 & 13 & 9.1 & 0.04 & 8.1 & 0.00 & 27 & 0 & 21 & 31 & 0 \\
\hline Cullinan & Diamond & 85 & 9 & 3 & 9.9 & 0.08 & 2.9 & 0.04 & 0 & 0 & 15 & 85 & 0 \\
\hline Rustenburg & Chromium & 91 & 6 & 3 & 8.9 & 0.01 & 1.2 & 0.02 & 4 & 0 & 13 & 80 & 2 \\
\hline Rustenburg & Platinum & 83 & 11 & 5 & 8.7 & 0.02 & 19.7 & 0.08 & 7 & 0 & 27 & 0 & 15 \\
\hline Witbank & Coal & 61 & 25 & 13 & 7.6 & 15.62 & 5.9 & 0.18 & 48 & 0 & 0 & 0 & 41 \\
\hline Rustenburg & Silica & 9 & 56 & 25 & 6.0 & 0.27 & 3.3 & 0.49 & 43 & 27 & 0 & 0 & 28 \\
\hline Stilfontein 1 & Gold & 48 & 38 & 12 & 2.7 & 0.05 & 9.6 & 0.51 & 1 & 15 & 39 & 0 & 37 \\
\hline Stilfontein2 & Gold & 45 & 44 & 11 & 7.6 & 0.03 & 12.2 & 0.08 & 0 & 30 & 22 & 0 & 44 \\
\hline Brits & Vanadium & 92 & 6 & 0.3 & 9.1 & 0.07 & 9.1 & 0.31 & 39 & 0 & 0 & 0 & 27 \\
\hline
\end{tabular}

$\mathrm{pH}^{*}$ : pH, measured in water; OC: organic carbon content; ESP: exchangeable sodium percentage; CBD Fe: dithionite extractable iron; Kao: kaolinite; Mi: Mica; Tc: Talc; Py: Pyrophyllite; Sm: smectite; Qz: quartz; Fs: Felds [par; Ex.: exchangeable; *: cmol kg-1;

CEC: cation exchange capacity; Sand (2.0-0.106 mm); Silt (106-2 $\mu \mathrm{m})$; Clay $(<2 \mu \mathrm{m})$.

Some $50 \mathrm{~kg}$ of material was collected of each of the waste areas. Samples were dried at $40^{\circ} \mathrm{C}$ and gently ground to pass a $2 \mathrm{~mm}$ sieve. Selected textural, chemical and mineralogical parameters were determined using routine analytical methods (NONAFFILIATED SOIL ANALYSIS WORK COMMITTEE, 1990).

For rainfall simulation, the samples were packed in $350 \mathrm{~mm} \times 500 \mathrm{~mm}$ boxes, $20 \mathrm{~cm}$ deep over an $80 \mathrm{~mm}$ deep layer of coarse sand. The boxes were placed in the rainfall simulator on a $15^{\circ}$ slope, water-saturated from the bottom and then subjected to high-energy rain until a steady final infiltration rate was observed. The median drop velocity was $6.02 \mathrm{~m}$ $\mathrm{s}^{-1}$, the kinetic energy $18.1 \mathrm{~J} \mathrm{~mm}-1 \mathrm{~m}^{-2}$ and the rain intensity $45 \mathrm{~mm} \mathrm{~h}^{-1}$ for $1.67 \mathrm{~h}$. Distilled water (electrical conductivity value $1.0 \mathrm{mS} \mathrm{m}^{-1}$ ) was used to simulate second time (Run 2). Run 2 took seal/crust formation into account. The erosion variables surface runoff (RO) and sediment yield (SL) were determined, as described by Levy (1988), using a rainfall simulator model developed in Israel (MORIN et al., 1967). Interrill erodibility EPP was determined according to Laflen et al. (1991). These erosion variables were determined for the bare tailings and repeated on the same materials, covered with palm-mats.

\section{São Luis City (Brazil)}

In Sacavém gully slopes was applied soil bioengineering techniques, considering biological geotextile constructed from Buriti palm. The aim was to minimize soil erosion, by intercepting rainfall, retarding runoff velocity and sediment loss. These 

Antonio José Teixeira Guerra, José Fernando Rodrigues Bezerra, Luis Dias da Mota Lima, Jane Karina Silva Mendonça, Tatiana Teixeira Guerra, Christl Buhmann, David Garry Paterson, Gerry Pienaar, J. Piet Nell, Nthanyiseni Elvis Mulibana, Pieter Willem Van

techniques included: 1 . Buriti geotextiles in association with barriers of wooden stakes (Figure 3 ) and the construction of terraces along contour lines; 2 . Analysis of sediment particle-size; and 3. Photo comparison of vegetation cover development.

The rehabilitation work used $\sim 30 \mathrm{~kg}$ of grass seeds (Brachiaria decumbens) on the slopes in combination with geotextiles. The shrub Sabiá (Mimosa caesalpiniae folia) was used on the higher parts of the gully, to protect the topsoil. The rehabilitated area was fertilized with $500 \mathrm{~kg} \mathrm{ha}^{-1}$ of NPK (4-14-8) and decomposing palm was added to topsoil, as a source of organic matter. The project employed 10 local men for six days, who conducted the work using hand-held tools (Figure 4). A tractor (type backhoe loader) was used for two days to construct the terraces (Figure 5).

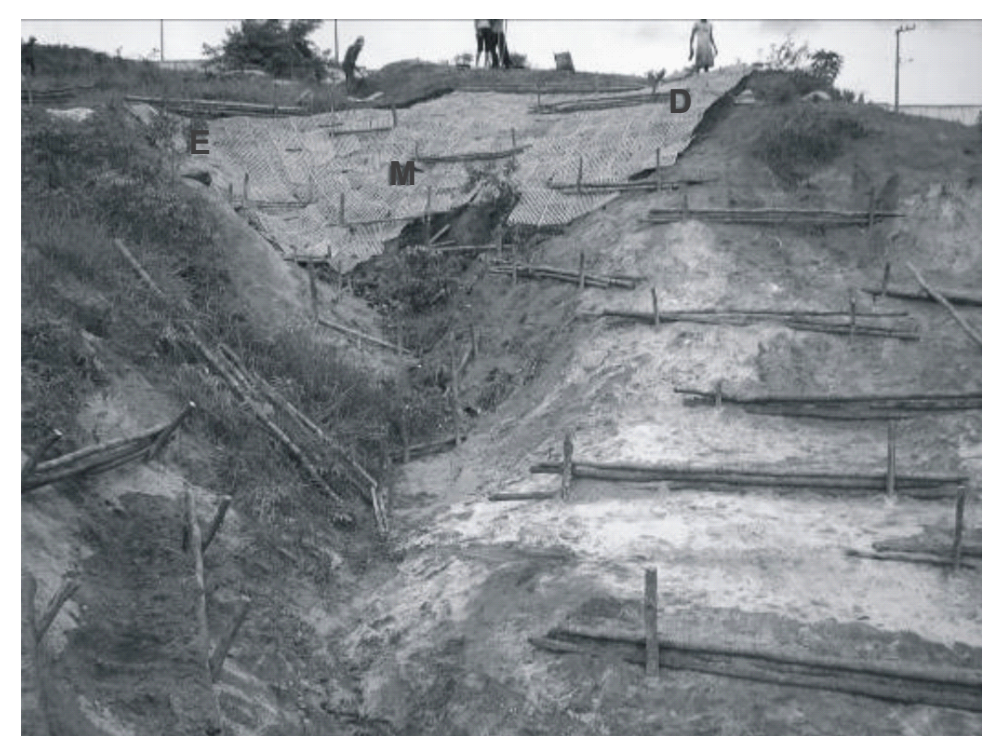

Figure 3: Area 3 of the rehabilitated area, with work in progress. E, M and D were reshaped exclusively by manual labour, São Luís, Brazil. Source: LAGESOLOS, 2008.

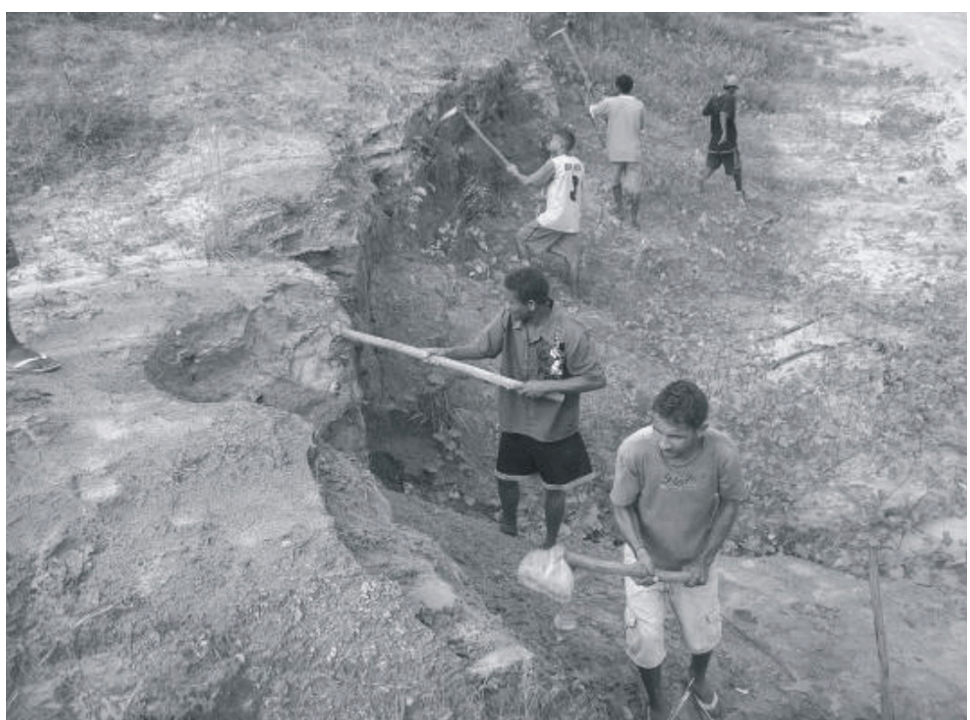

Figure 4: Men working with hand-held tools, São Luís, Brazil. Source: LAGESOLOS, 2008. 


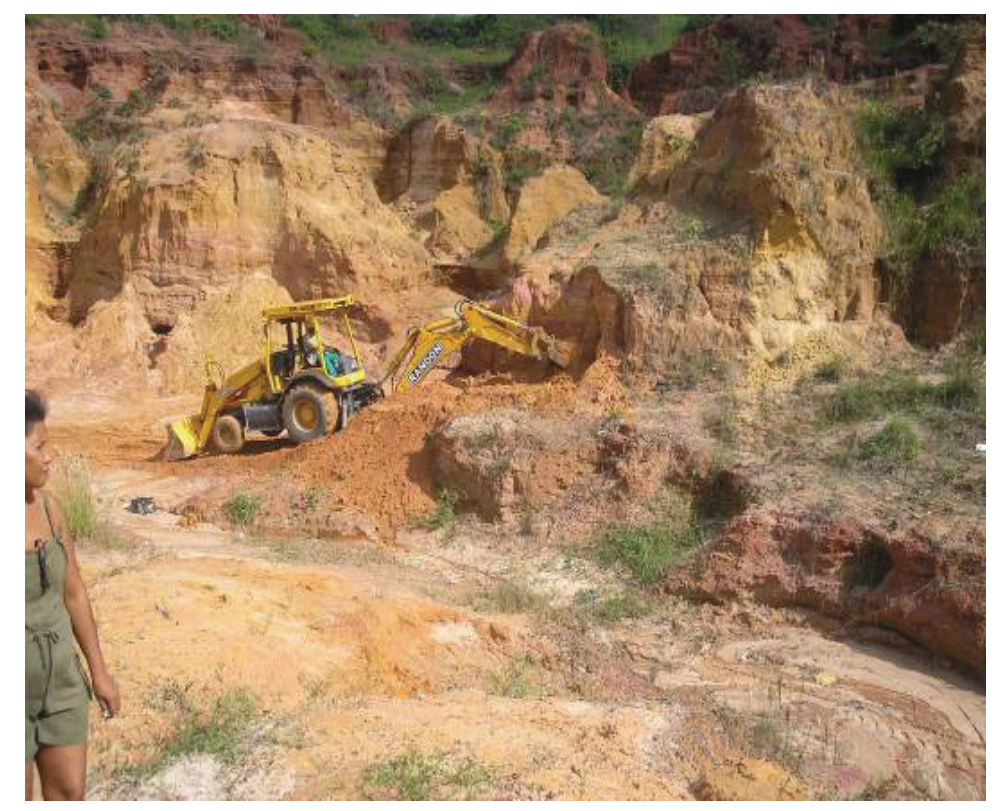

Figure 5: Initial work in areas 4-8. Source: LAGESOLOS, 2008.

The rehabilitation work in Sacavém was divided into three areas, presented in Figures 4 and 5 , because of local relief characteristics. Areas 1-3 (Figure 6) were constructed with men and tractors; areas 4-8 (Figure 6) were made in the higher parts with a tractor; and areas E, M and D (Figure 3) were reshaped exclusively by manual labour.
In Part 1 (Figure 6: areas 1-3) the team used biological geotextiles and organic matter from decomposing palms, seeds and inserted barriers of wooden stakes along contour lines. This area had formed due the concentration of runoff from the street above the gully (Figure 7).

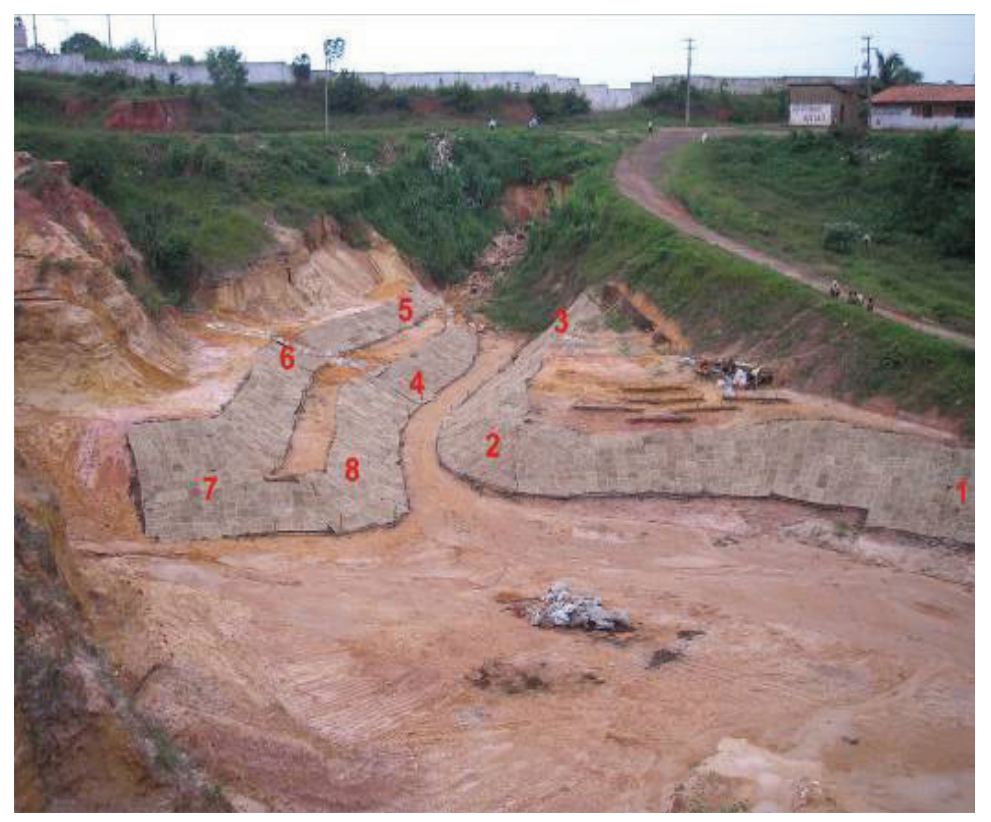

Figure 6: Rehabilitated areas with cover of buriti geotextiles, Sacavém Community, São Luís, Brazil (Areas 1-3 were constructed with men and tractors; areas 4-8 were made in the higher parts with a tractor). Source: LAGESOLOS, 2008.

Sociedade \& Natureza, Uberlândia, 22 (3): 431-446, dez. 2010 


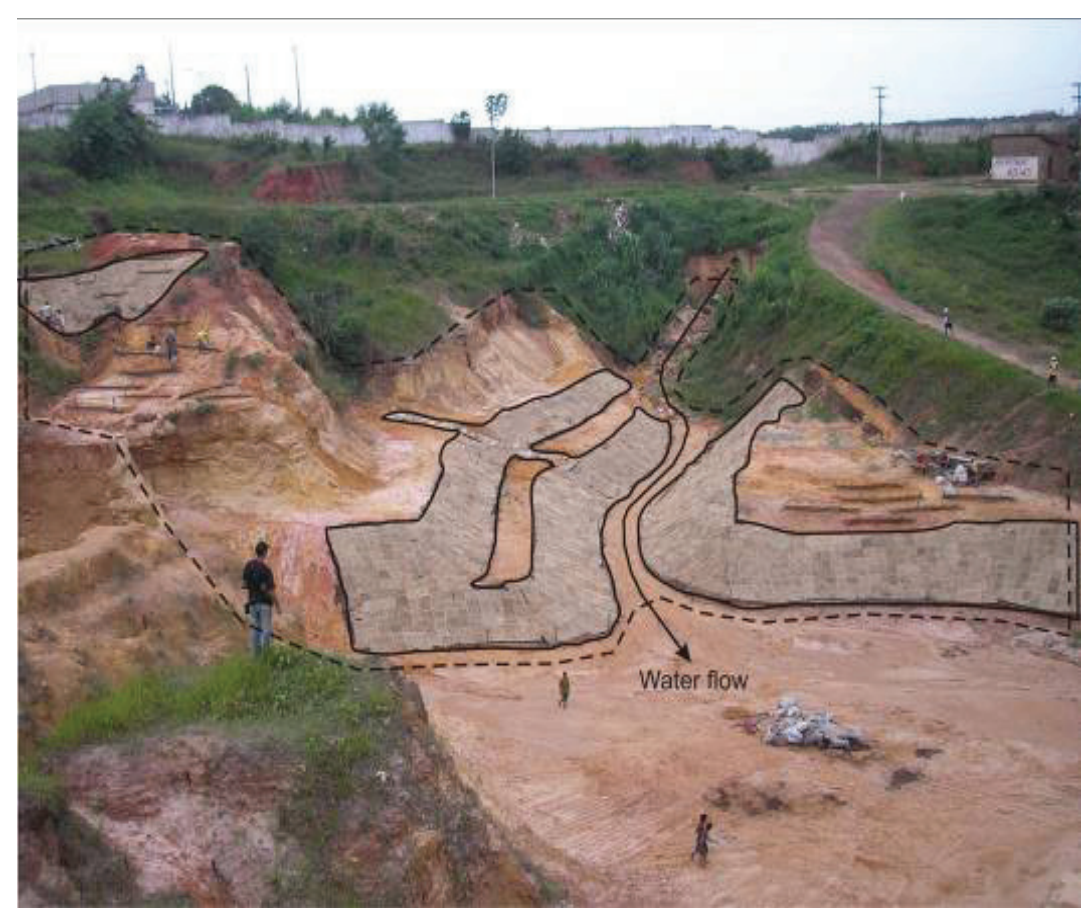

Figure 7: Continuous lines: areas rehabilitated with Buriti palm mats.

Hatched lines: the rehabilitated area in Sacavém Community, São Luís, Brazil. Source: LAGESOLOS, 2008.

Area 2 was mostly made by the tractor, to construct the terraces by reshaping the gullies. This part was formed by water flows collected from the street, and was totally modified by tractor work. Here there was evidence of active erosion, in the form of rills. After the tractor's work, the manual reshaping of slopes and the application of biological geotextiles was achieved manually.

Area 3 was made by men using Buriti biological geotextiles, organic matter from decomposing organic material (palm trees and leaves), wooden stakes and the planting of shrubs, as inaccessibility prevented tractor work. To reshape the internal part of the gully, we used techniques to minimize water flow energy, using many barriers of wooden stakes (Figure 3 ) and the application of biological geotextiles, grass seeds and organic matter from decomposing palm leaves. On the barriers, Sabiá bushes were planted to stabilize the topsoil. The rehabilitated area in Sacavém Community is $\sim 2000 \mathrm{~m}^{2}$ and $\sim 800 \mathrm{~m}^{2}$ is covered with Buriti biological geotextiles (Figure 7).

Studies were carried out in the laboratory using soil samples collected from Sacavém gully walls and from the gully floor to determine particle- size distribution, using EMBRAPA (1997) protocols. Vegetation cover index was monitored and assessed on Sacavém rehabilitation site, using photographs and supervised classification tools available in Arcgis 9.3, which can perform pixel-based classification. The progress of vegetation cover was monitored weekly from March 2008 to May 2008. These photos were taken at the same point, using wood stakes on the rehabilitated slope.

\section{RESULTS AND DISCUSSION}

\section{Gauteng Province (South Africa)}

Over 200,000 ha of natural habitat have been degraded by mining activities in South Africa. Tailing dams are responsible for many of these environmental problems. Establishing a grass cover to reduce erosion is the dominant reclamation method. Chemical methods, such as lime, fertilizer and compost applications, are generally used (VAN DEVENTER; MARAIS, 2003). Covering the slopes with biological geotextiles might constitute another option for mining companies to reduce erosion and aid re-vegetation. 


\section{-Waste properties}

The waste samples varied considerably with respect to their textural, chemical and mineralogical properties (Table 1). Most were sand-textured and the clay content was low. The $\mathrm{pH}$ ranged from 2.7-9.9, with seven samples being alkaline and three acidic. With the exception of the coal waste sample, organic carbon (OC) contents were low $(<0.27 \%)$. Dithioniteextractable iron (CBD-Fe) contents were generally low, particularly in the tailings, and the exchangeable cation population was dominated by $\mathrm{Ca}$. Exchangeable Na percentages (ESP) ranged from 1.2-19.7. Some clay fractions were dominated by kaolinite, smectite, mica, pyrophyllite or quartz. These results are characteristic of the broad range of South African mine wastes.

\section{- Rainfall simulator results}

Although experimental conditions under the rainfall were made as identical as possible, significant differences existed in the investigated erodibility variables (RO, SL, WEPP) (Table 2).

\section{-Sediment load in runoff (SL)}

SL in runoff $(\mathrm{g})$ ranged from 0.5 to 699 , with a mean of 248 for Run 1 and 223 for Run 2 (Table $2)$. Once the trays were covered with biological geotextiles, SL decreased considerably in all cases to a mean $\sim 55 \%$ of bare treatment. This indicates that palm-mats have very beneficial effects on erosion reduction.

\section{- Runoff (RO)}

Runoff $\left(\mathrm{cm}^{-3}\right)$ ranged from 391 to 4295 with a mean of $2655 \mathrm{~cm}^{3}$ in Run 1 and almost identical values for Run 2. When the samples were covered with biological geotextiles, mean runoff values remained the same for Run 1 and slightly decreased for Run 2 (Table 2). This indicates that biological geotextiles do not always reduce runoff values. The following trends between selected waste parameters and interrill erodibility have been established: the silt percentage, commonly regarded as one of the most influential erosion-promoting parameters and featuring prominently in $\mathrm{K}$ equations, was also one of the most relevant erosion parameters in the present study. Clay content influenced RO, but not SL. The influence of texture became more pronounced when the tailings were covered with mats; quartz and mica were the dominant clay parameters governing interrill erodibility; the ESP, often associated with erosion, did not show any distinct relationship to SL; EPP increased with: a) increasing silt content; b) increasing quartz and mica proportions in the clay fraction and c) decreasing sand content and $\mathrm{pH}$; the findings that materials which have their clay fractions dominated by quartz and/or mica are far more erodible than smectitic or kaolinitic ones and that a high ESP does not necessarily promote erosion are noteworthy.

Table 2: Minimum, maximum and mean (in brackets) values of selected erosion variables.

\begin{tabular}{|c|c|c|c|}
\hline & Sediment load $(\mathrm{g})$ & $\begin{array}{c}\text { Runoff } \\
(\mathrm{cm} 3)\end{array}$ & $\begin{array}{c}\text { WEPP\# } \\
\text { (kg.s.m-4) }\end{array}$ \\
\hline $\begin{array}{c}\text { Bare samples } \\
\text { Run 1 }\end{array}$ & $0.5-699(248)$ & $391-4295(2655)$ & $\begin{array}{c}0.06-6.53 \\
(2.24)\end{array}$ \\
\hline $\begin{array}{c}\text { Bare samples } \\
\text { Run 2 }\end{array}$ & $6.5-551(223)$ & $419-4254(2724)$ & $\begin{array}{c}0.06-5.15 \\
(1.96)\end{array}$ \\
\hline $\begin{array}{c}\text { Palm-mat cover } \\
\text { Run 1 }\end{array}$ & $8.5-328(122)$ & $383-4497(2658)$ & $\begin{array}{c}0.16-3.06 \\
(1.34)\end{array}$ \\
\hline $\begin{array}{c}\text { Palm-mat cover } \\
\text { Run 2 }\end{array}$ & $4-244(98)$ & $386-4432(2569)$ & $0.03-2.27$ \\
\end{tabular}

EPP\#: Erodibility according to the WEPP model. Source: Laflen et al., 1991. 


\section{São Luis City (Brazil)}

\section{- Rehabilitation work}

Due to the difficulties in diverting the flows, which would require more extensive engineering works, the channel was maintained, and the base of the slopes was strengthened to support the flows (Figure 7: arrow). In the upper part of this area, which had $\sim 8^{\circ}$ slope angle, contour lines were surveyed and barriers of wooden stakes were used to retard runoff velocity from adjacent vegetated slopes. Some slopes in this part had a $45^{\circ}$ slope angle (Figure 6: part 3). However, this angle is considered too steep for the application of biological geotextiles.
In area 2, work was completed to reshape the gullies and construct the $\sim 12 \mathrm{~m}$ high terraces using the gully material. Tractor work was impeded, because on the second terrace the tractor had difficulty in working, because the high sand content made the slope unstable. These terraces are crossed by a flow convergence area, which was formed by the men inserting sand bags, decomposing palm leaves and grass seeds, to form a vegetated channel after grass growth.

Most erodible materials tend to be silts and sands, which are non-cohesive and sufficiently small to be transported by the flow rates characteristic of rills (FULLEN and CATT, 2004). In the study area, soil textural analysis confirms the coarse texture (Ta-

Table 3: The texture of soil samples from Sacavém gully.

\begin{tabular}{|c|c|c|c|}
\hline Samples & Sand (\%) & Silt (\%) & Clay (\%) \\
\hline 1 & 96.67 & 2.23 & 1.10 \\
\hline 2 & 68.46 & 23.04 & 8.50 \\
\hline 3 & 83.25 & 9.25 & 7.50 \\
\hline 4 & 92.85 & 2.75 & 4.40 \\
\hline 5 & 94.76 & 2.14 & 1.10 \\
\hline 6 & 96.60 & 1.60 & 1.80 \\
\hline 7 & 94.15 & 1.05 & 10.50 \\
\hline 8 & 78.97 & 10.53 & 2.50 \\
\hline 9 & 94.12 & 3.38 & \\
\hline
\end{tabular}

Sand $=2000-50 \mu \mathrm{m}$, silt $=50-2 \mu \mathrm{m}$ and clay $=<2 \mu \mathrm{m}$.

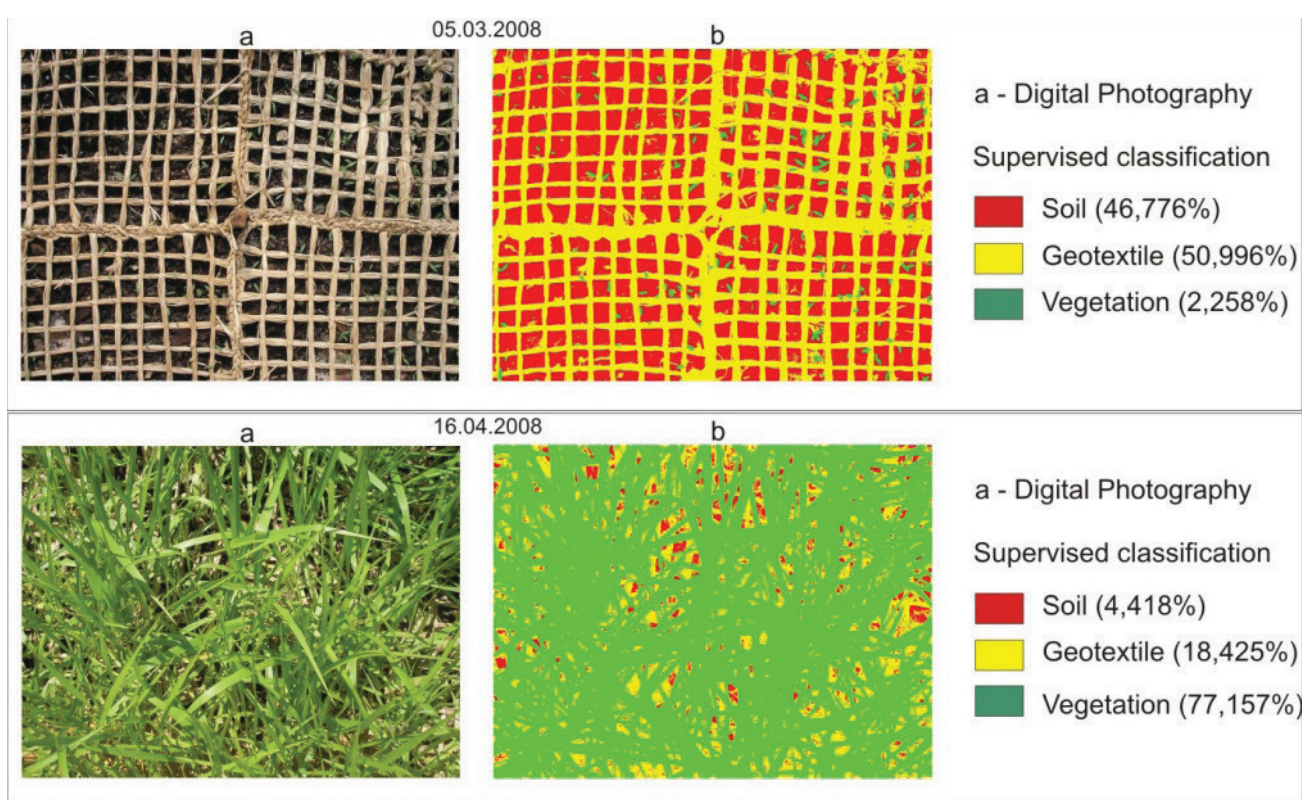

Figure 8: Photo comparison of vegetation cover developing in Sacavém community, São Luís, Brazil. 
ble 3). The samples had high sand (68.46-96.67\%) and fine sand (1.10-10.50\%) contents and low silt (1.05-23.04\%) and clay (5.00-26.98\%) contents. Soil organic matter contents are low ( $\sim 1 \%$ by weight) and are even less in the subsoil. These soil properties indicate high erodibility. Clay lenses were present at $\sim 2.5 \mathrm{~m}$ depth (Figure 6: areas 4-8). Because of this, the tractor worked better than in the second sandier terrace. According to photo comparison data, in one month the vegetation had developed (Figures 8 and 9). Continued success requires continued high-quality maintenance, which is being achieved by local people, under project supervision.

For one month after the rehabilitation work São Luís City experienced intense and prolonged rains (Table 4), which presented attendant problems for the rehabilitation work. However, we again employed local people to work on site maintenance (Figure
10). This shows that we cannot assume that the entire rehabilitation process will be successful, especially when one is working in an erosive tropical climate. However, we have succeeded to date. The storm had a recurrence interval of $\sim 60$ years and, apart from some minor damage on parts of the rehabilitated area, there has been only some minor erosion, especially where some water convergence occurred. This evidence suggests the work will prove successful. The ongoing site development can be monitored via the LAGESOLOS (Laboratory of Environmental Geomorphology and Soil Degradation, Federal University of Rio de Janeiro) web site: $<$ http://www.lagesolos.ufrj.br>.

Textural data show that the main component materials of the slopes at Sacavém gully are sands, with many samples being $>90 \%$ sand (Table 3 ). Thus, the soils are highly erodible and, therefore, the use of biological geotextiles is very important to arrest the erosion process.

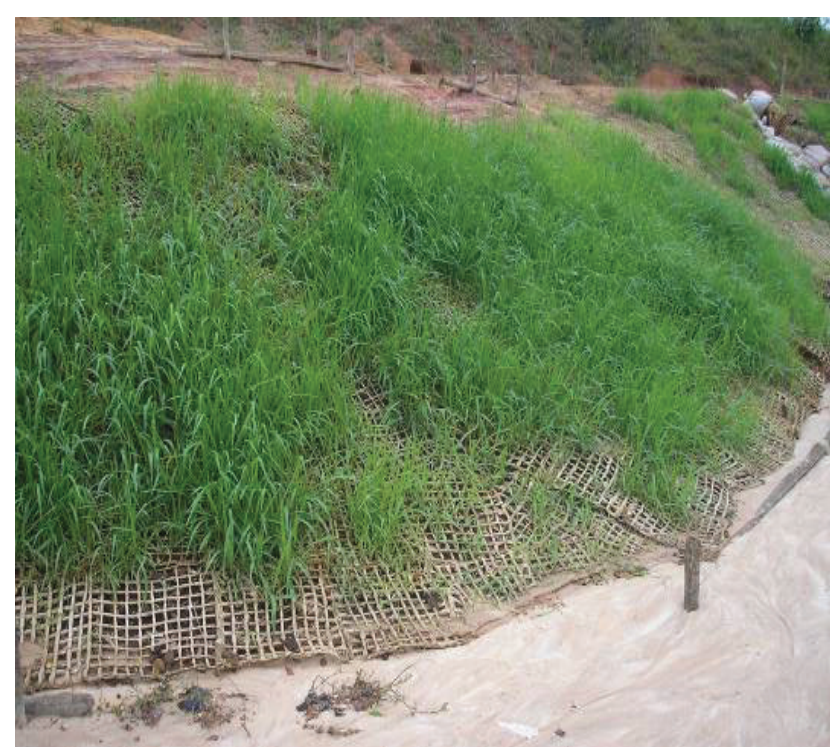

Figure 9: Grass development, one-month after rehabilitation,

Sacavém community, SãoLuís, Brazil. Source: LAGESOLOS, 2008.

Table 4: Daily meteorological data from São Luís City (10/03/08-09/04/08).

\begin{tabular}{c|c|c|c|c}
\hline Min. Temp. $\left({ }^{\circ} \mathrm{C}\right)$ & Max. Temp. $\left({ }^{\circ} \mathrm{C}\right)$ & Relative Humidity $(\mathbf{\%})$ & Rain (mm) & Date \\
\hline 23.3 & 30.8 & 76.0 & 5.0 & $10 / 03 / 2008$ \\
\hline 24.4 & 31.5 & 78.0 & 0.0 & $11 / 03 / 2008$ \\
\hline 24.2 & 30.4 & 78.0 & 0.0 & $12 / 03 / 2008$ \\
\hline 22.8 & 29.8 & 80.0 & 22.0 & $13 / 03 / 2008$ \\
\hline 23.2 & 26.4 & 91.0 & 8.6 & $14 / 03 / 2008$ \\
\hline 22.8 & 29.4 & 85.0 & 8.6 & $15 / 03 / 2008$ \\
\hline
\end{tabular}


Land rehabilitation with the use of biological geotextiles, in two different countries Antonio José Teixeira Guerra, José Fernando Rodrigues Bezerra, Luis Dias da Mota Lima, Jane Karina Silva Mendonça, Tatiana Teixeira Guerra, Christl Buhmann, David Garry Paterson, Gerry Pienaar, J. Piet Nell, Nthanyiseni Elvis Mulibana, Pieter Willem Van Deventer, Michael Augustine Fullen

\begin{tabular}{|c|c|c|c|c|}
\hline 22.9 & 28.4 & 70.0 & 83.0 & $16 / 03 / 2008$ \\
\hline 23.8 & 29.4 & 75.0 & 10.6 & $17 / 03 / 2008$ \\
\hline 23.0 & 26.3 & 82.0 & 28.6 & $18 / 03 / 2008$ \\
\hline 23.3 & 28.0 & 81.0 & 27.1 & $19 / 03 / 2008$ \\
\hline 22.9 & 30.3 & 71.0 & 0.4 & $20 / 03 / 2008$ \\
\hline 23.0 & 29.6 & 73.0 & 37.3 & $21 / 03 / 2008$ \\
\hline 23.2 & 29.2 & 77.0 & 0.0 & $22 / 03 / 2008$ \\
\hline 23.9 & 30.0 & 74.0 & 2.3 & $23 / 03 / 2008$ \\
\hline 23.9 & 27.6 & 80.0 & 37.6 & $24 / 03 / 2008$ \\
\hline 24.0 & 30.0 & 78.0 & 1.8 & $25 / 03 / 2008$ \\
\hline 23.4 & 29.4 & 84.0 & 34.6 & $26 / 03 / 2008$ \\
\hline 23.6 & 27.4 & 89.0 & 24.2 & $27 / 03 / 2008$ \\
\hline 23.2 & 30.0 & 74.0 & 38.6 & $28 / 03 / 2008$ \\
\hline 24.3 & 29.0 & 77.0 & 0.4 & $29 / 03 / 2008$ \\
\hline 23.4 & 27.6 & 95.0 & 10.6 & $30 / 03 / 2008$ \\
\hline 23.8 & 28.9 & 86.0 & 28.6 & $31 / 03 / 2008$ \\
\hline 23.6 & 28.7 & 87.0 & 102.2 & $01 / 04 / 2008$ \\
\hline 23.0 & 29.5 & 67.0 & 97.8 & $02 / 04 / 2008$ \\
\hline 22.7 & 29.4 & 74.0 & 29.6 & $03 / 04 / 2008$ \\
\hline 24.3 & 30.4 & 70.0 & 3.1 & $04 / 04 / 2008$ \\
\hline 24.2 & 26.2 & 90.0 & 0.0 & $05 / 04 / 2008$ \\
\hline 22.0 & 27.0 & 81.0 & 71.8 & $06 / 04 / 2008$ \\
\hline 23.3 & 31.2 & 68.0 & 3.7 & $07 / 04 / 2008$ \\
\hline 23.8 & 29.7 & 83.0 & 35.6 & $08 / 04 / 2008$ \\
\hline 23.8 & 31.2 & 77.0 & 0.0 & $09 / 04 / 2008$ \\
\hline- & - & $\Sigma$ & 753.7 & - \\
\hline
\end{tabular}

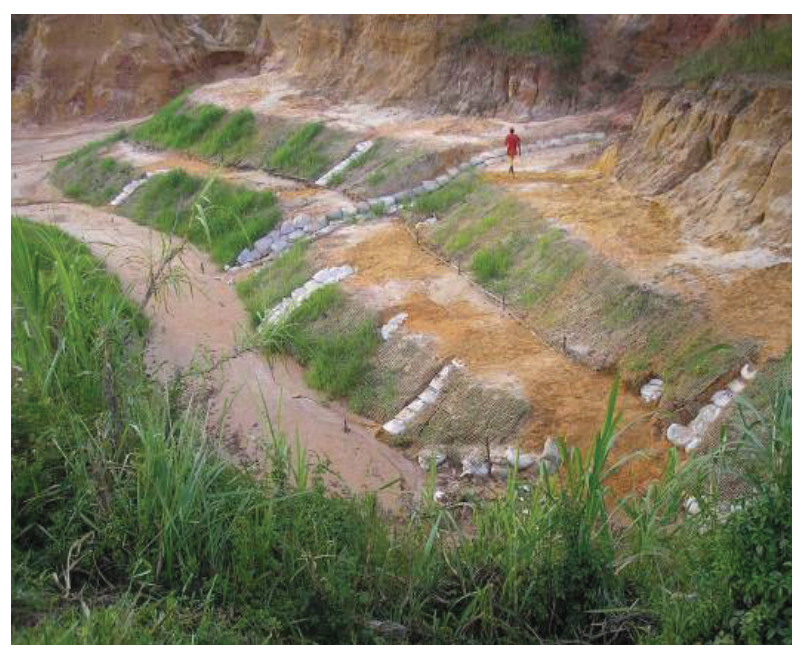

Figure 10: Maintenance work at the rehabilitated area one month after rehabilitation, Sacavém community, São Luís, Brazil. Source: LAGESOLOS, 2008.V 


\section{CONCLUSIONS}

The conclusions for this paper take into account each presented study area. In this way, we can address the role of biological geotextiles on the stability of non-agricultural environments in two different countries. The objective was reached by a combination of field, experimental and laboratory studies, which suggest biological geotextiles constructed from palm leaves are an effective, sustainable and economically-viable soil conservation technique. It can be used to improve ecosystem management, decreasing deforestation, improving agroforestry and cost-effective applications in diverse environments.

Environmental and socio-economic rewards of biological geotextiles suggest they could be an effective and inexpensive soil conservation method, with enormous global potential. The postulated strategic impacts of biological geotextiles include promoting sustainable and environmentally-friendly palm-agriculture, which discourages deforestation, promoting both reforestation and agroforestry and the technique may be potentially profitable and thus augment the income of financially-deprived communities. Hence, construction of palm geotextiles could develop into a rural, labour-intensive industry, particularly encouraging the employment of socially-disadvantaged groups, such as women, disabled and elderly people (i.e. hand-work performed sitting down).

These techniques have been applied in different countries, with positive results from the use of biodegradable materials (e.g. vegetal fibres, wooden stakes and re-vegetation). These techniques stabilize the soil at low cost and improve the environment. Bioengineering involves the planned, strategic and phased application of selected materials, involving biodegradable materials, often in combination with 'hard engineering' structures constructed from stone, concrete and steel.

In Gauteng Province (South Africa), the results from rainfall simulator experiments clearly illustrate that application of palm-mats significantly decreased sediment load in runoff, thereby having the potential to effectively stabilize tailing dam slopes.
Covering tailings with biological geotextiles did not reduce runoff or improve water infiltration, however. Tailings that have their clay fraction dominated by quartz and are silt textured are particularly prone to erosion.

Accelerated erosion in Sacavém District (São Luís City) is enhanced by the action of intense rains, acting in combination with vegetation clearance and the erodible sandy soil texture. Intense human action, with inadequate soil use and irregular settlement, also plays a very important role in gully erosion. Only one month after the rehabilitation work, the area was exposed to intense erosive rains. Vegetation resisted erosion and the Buriti geotextiles seem to have achieved our main objective, that is, to stop soil erosion and rehabilitate the gullied area.

The main purpose of this study was to assess the effects of biological geotextiles on the stability of non-agricultural environments, considering different sites and methods. Although different techniques were used, the results indicate that positive effects of biological geotextiles can be achieved. First, biological geotextiles offer potential for sustainable development and soil conservation. Second, they can also be used for economic development, creating jobs and reducing poverty in poor rural and urban regions. Finally, the rehabilitation of degraded soils at these sites using biological geotextiles may help to recover stable conditions.

\section{ACKNOWLEDGEMENTS}

This research forms part of the BORASSUS Project 'The environmental and socio-economic contributions of palm-leaf geotextiles to sustainable development and soil conservation' (contract number: INCO-CT-2005-510745), funded by the European Commission (EC), Specific Targeted Research Projects (FP6-STREPs) for Developing Countries (INCODEV) Programme. This Project is dedicated to the memory of Dr Kathy Davies, who was the initiator and inspiration for palm-leaf geotextile research. We are grateful to Professor Mike Fullen (University of Wolverhampton) for having read the first version of this paper and having made useful suggestions. 


\section{REFERENCES}

BEZERRA, J.F.R.; GUERRA A. J. T.; FULLEN M.; TELES T. Soil Bioengineering applied to soil erosion in São Luís City, Brazil. In: HUMAN IMPACT ON GULLY EROSION, 5TH INTERNATIONAL SYMPOSIUM ON GULLY EROSION, 2010, Lublin, Poland. Human Impact on Gully Erosion, Lublin, Poland, 2010.

CASAL, J.; LOPEZ, J. J.; GIRALDEZ J. V. Ephemeral gully erosion in southern Navarra (Spain). Catena, 36, p. 65-84, 1999.

DEPARTMENT OF AGRICULTURE, CONSERVATION AND ENVIRONMENT. State of the Environment in Gauteng. Directorate of Environment, P.O. Box. 8769, Johannesburg. 2004.

EMBRAPA. Manual de Métodos e Análises Solo. Rio de Janeiro, EMBRAPA/SNLCS. 1997.

FONSECA, M. J. B. A Invasão como Processo de Ocupação dos Espaços Urbanos Vazios: o caso Vila Lobão - São Luís - MA. São Luís, 1995.

FULLEN, M. A. Soil erosion and conservation in Northern Europe. Progress in Physical Geography, 27, p. 331-358, 2003.

FULLEN, M. A, CATT, J. A. Soil Management: Problems and Solutions. Arnold, London, 2004.

GABRIELS, D.; SCHOETTECATTE, W.; JIN, K.; CAI, D.; HARTMANN, R. Runoff and sediment transport under field simulated rainfall in the eastern part of the Loess Plateau in China. In: 17TH WORLD CONGRESS OF SOIL SCIENCE, Bangkok, Thailand, Proceedings... Bangkok, Thailand, 2002.

GOUDIE, A. S. Dryland degradation. In: ROBERTS, N. (Ed.) The Changing Global Environment. Blackwell, Oxford, 1994. p. 351-368.

GUERRA, A. J. T.; MARCAL, M.; POLIVANOV, H.; SATHLER, R.; MENDONÇA, J.; GUERRA, T.; BEZERRA, F.; FURTADO, M.; LIMA, N.;
SOUZA, U.; FEITOSA, A.; DAVIES, K.; FULLEN, M. A.; BOOTH, C. A. Environmental management and health risks of soil erosion gullies in São Luís (Brazil) and their potential remediation using palmleaf geotextiles. In: BREBBIA, C.A.; POPOV, V.; FAYZIEVA, D. (Ed.) Environmental Health Risk III. Wessex Institute of Technology Press, 2005. p. $459-467$.

GUERRA, A. J. T. Processos erosivos nas encostas. In: CUNHA, S. B.; GUERRA, A. J. T (Ed.). Geomorfologia: exercícios, técnicas e aplicações. Rio de Janeiro (Brazil): Bertrand, 2000. p. 139-155.

GUERRA, A. J. T.; MENDONCA, J. K. S.; MARCELO, R.; ALVES, I. S. Gully erosion monitoring in São Luis City - Maranhão State - Brazil. In: LI Y, Poesen J.; VALENTIN, C. (Ed.) Gully Erosion Under Global Change. Chengdu, China: Sichuan Science and Technology, 2004. p. 13-20.

HOWARD, A. D. Simulation of gully erosion and bistable landforms. In: WANG, S.S.Y., LANGENDOEN, E.J.; SHIELDS, F.D. (Ed.) Proceedings of the Conference on Management of Landscapes Disturbed by Channel Incision. Center for Computational Hydroscience \& Engineering, The University of Mississippi, Oxford MS, 1997. p. 516-521.

LAFLEN, J. M.; LANE, L. J.; FOSTER, G. R. WEPP: A new generation of erosion prediction technology. $J$. Soil Water Conservation, 46, p. 34-38, 1991.

LEDIN, M.; PEDERSEN, K. The environmental impact of mine wastes - Roles of micro-organisms and their significance in treatment of mine wastes. Earth-Science Reviews. 41, p. 67-108. 1996.

LEVY, G. J. The effects of clay mineralogy and exchangeable cations on some of the hydraulic properties of soils. 1988, 129p. PhD. Thesis (unpub.), Univ. Pretoria, South Africa, 1988.

MARANHÃO. 'Secretaria de Estado do Meio Ambiente e Recursos Hídricos'. Diagnóstico ambiental da Microrregião da Aglomeração Urbana de São Luís 
e dos municípios de Alcântara, Bacabeira, Rosário e São Luís. Relatório técnico. 1998.

MORIN, J.; GOLDBERG, S.; SEGINER, I. A rainfall simulator with a rotating disk. Trans. Am. Soc. Agric. Engrs. 10: 74-79. 1967.

MORGAN, R. P. C. Soil Erosion and Conservation. Third edition. Blackwell Publishing, Oxford, England, 2006.

MUNRO, R. N.; DECKERS, J.; HAILE, M.; GROVE, A. T.; POESEN, J.; NYSSEN, J. Soil landscapes, land cover change and erosion features of the Central Plateau region of Tigrai, Ethiopia: Photo-monitoring with an interval of 30 years. Catena, v. 75, issue 1, p. 55-64, set. 2008.

NON-AFFILIATED SOIL ANALYSIS WORK COMMITTEE. Handbook of Standard Soil Testing Methods for Advisory Purposes. Soil Sci. Soc. S. Africa, Pretoria, South Africa, 1990.

POESEN, J; NACHTERGAELE, J.; VERSTRAETEN, G.; VALENTIN, C. Gully erosion and environmental change: importance and research needs. Catena, 50, p. 91-133, 2003.

SATHLER, R.; GUERRA, A. J. T.; POLIVANOV, H.; MARÇAL, M. Erosive processes in urban areas in the island of Maranhão - Brazil. Sociedade \& Natureza, Uberlândia, Special Issue, p. 161-173, 2005.

SOBREIRA, F. G. A ocupação desordenada nas encostas de Ouro Preto, MG. Revista Escola de Minas. 42, p. 12-16, 1989.

VALENTIN, C.; AGUS, F.; ALAMBAN, R.; BOOSANER, A.; BRICQUET, J. P.; CHAPLOT, V.; GUZMAN, T. D.; ROUW, A.; JANEAU, J.L.; ORANGE, D.; PHACHOMPHONH, K.; PHAI, D.; PODWOJEWSKI, P.; RIBOLZI, O.; SILVERA, N.; SUBAGYONO, K.; THIÉBAUX, J. P.; TRAN D. T.; VADAR, T. I. H. Runoff and sediment losses from 27 upland catchments in Southeast Asia: Impact of rapid land use changes and conservation practices.
Agriculture, Ecosystems \& Environment, v. 128, issue 4, p. 225-238, dec. 2008.

VAN DEVENTER, P.W.; MARAIS, M. Consolidated Closure Plan for the Chemwes Environmental Remediation Project. Report submitted to the Dept. Min. Energy, Klerksdorp. 2003.

Sociedade \& Natureza, Uberlândia, 22 (3): 431-446, dez. 2010 